DOI 10.15290/cnisk.2017.02.03.07

DR HAB. MAGDALENA MUSIAt-KARG, PROF. UAM

orcid.org/0000-0002-6089-1381

Uniwersytet im. Adama Mickiewicza w Poznaniu

\title{
Kobiety na rynku pracy - analiza uwarunkowań
}

\section{Streszczenie}

Problematyka roli i miejsca kobiet w przestrzeni publicznej, czyli $\mathrm{w}$ społeczeństwie, na rynku pracy i w szeroko rozumianej polityce, jest tematem coraz częściej poruszanym przez wielu naukowców, dziennikarzy, obserwatorów i komentatorów życia społecznego, gospodarczego i politycznego. Zachodzace we współczesnym świecie zmiany społeczne i gospodarcze stwarzaja warunki, które sprzyjaja zwiększeniu liczby kobiet na rynku pracy, współuczestniczeniu w procesie zarządzania, a także wzrostowi ich ambicji zawodowych. Mimo tego można wskazywać na wiele trudności i problemów związanych $z$ ich pozycją i sytuacją. Biorąc pod uwagę strefę biznesu, wyraźnie widać niedoreprezentowanie kobiet, szczególnie na najbardziej eksponowanych stanowiskach. Naturalne zatem wydaja się pytania o przyczyny takiej sytuacji. Rozważania w niniejszym tekście skoncentrowano na niezwykle - wydaje się - ważkich zagadnieniach związanych $z$ problemami kobiet na rynku pracy. Celem jest zatem analiza wybranych uwarunkowań i determinantów majacych wpływ na udział kobiet na rynku pracy.

Slowa kluczowe: kobiety, rynek pracy, determinanty

\section{WOMEN ON THE LABOUR MARKET} - ANALYSIS OF THE CONDITIONS

\author{
Abstract \\ The role and place of women in society, on the labour market or in \\ politics is a subject which is increasingly recognized by many scientists,


journalists, observers and commentators. A tide of social and economic changes in today's world contribute to the increase in the number of women on the labour market and consequently enhance their participation in the management processes, as well as their professional ambitions. However, there are many difficulties and obstacles related to their situation and professional positions. Taking into consideration the business field, the women's underrepresentation is clearly visible, particularly in the most prominent positions. The author of the article provides the most important considerations related to the situation, conditions and problems of women on the labour market. Therefore, the purpose of this text is to analyse selected conditions that influence the participation of women in the professional working life.

Keywords: women, labour market, conditions

\section{Wprowadzenie}

Problematyka roli i miejsca kobiet w przestrzeni publicznej, czyli w społeczeństwie, na rynku pracy czy w szeroko rozumianej polityce, jest tematem coraz częściej poruszanym przez wielu naukowców, dziennikarzy, obserwatorów i komentatorów życia społecznego, gospodarczego i politycznego.

Przyjmowane na przestrzeni ostatnich lat perspektywy badawcze uwzględniaja szereg różnych czynników wpływających bezpośrednio lub pośrednio na sytuację kobiet w wyżej wymienionych obszarach. Nie sposób bowiem dokonywać tego typu analiz bez zwracania uwagi na przemiany demograficzne współczesnego świata, czynniki ekonomiczne, historię, uwarunkowania kulturowe i religijne, a także funkcjonujace stereotypy czy przypisywane kobietom określone role społeczne. Zakreślając problematykę badawczą i stawiając rozmaite tezy, należy mieć na uwadze fakt, że kobiety nie stanowią małej, niewiele znaczącej grupy, ale reprezentuja ponad 50\% światowej populacji. W zdecydowanej większości państw nie znajduje to jednak odzwierciedlenia ani w reprezentacji kobiet w strukturach władzy politycznej, ani w sferze gospodar- 
czej, a co więcej, kobiety często traktowane sa jako osoby drugiej kategorii, niemające prawa do kształcenia się, aktywności zawodowej, nie wspominając już o karierze politycznej. Nie sposób także nie wspomnieć o łamaniu praw kobiet - nie tylko, jakby się mogło wydawać, w krajach słabo rozwiniętych, ale również w tych państwach, które szczyca się wysokim rozwojem gospodarczym i stabilną, ugruntowana demokracją. W wielu $z$ tych państw można zaobserwować dyskryminację kobiet ze względu na płeć w szeroko pojętym życiu publicznym.

We współczesnej debacie nad rola kobiet oraz ich pozycja w społeczeństwie funkcjonuje przekonanie, że drzwi wielu dziedzin życia sa dla kobiet ciagle zbyt mało uchylone. Will Kymlicka zwraca uwage na przyczyny tego stanu rzeczy:

Jeśli jakąs grupę społeczną wyklucza się wystarczająco długo $z$ jakiegoś przedsięwzięcia, to mamy prawie 100 procent szans, że reguły tego przedsięwzięcia rozwina się w taki sposób, że grupa owa nie będzie do nich dostosowana ${ }^{1}$.

Zjawisko ograniczonego dostępu i małej liczby kobiet na wysokich stanowiskach można dostrzec na rynku pracy, ale także w innych przestrzeniach życia społecznego, np. w polityce.

Pomimo tego, że minione stulecie przyniosło - przynajmniej na Starym Kontynencie - długo oczekiwaną równość między kobietami i mężczyznami, która jest zresztą jedną $z$ podstawowych zasad europejskiego porządku prawnego, rzeczywista sytuacja kobiet pozostawia wiele do życzenia. Za przyczynę tego stanu rzeczy uznać należy nie tylko fakt, iż kobiety w porównaniu $z$ mężczyznami reprezentują obecnie większość europejskiej populacji, ale również to, że od dłuższego już czasu zmianie ulega postrzeganie roli kobiet w rodzinie i w społeczeństwie. Na przełomie wieków funkcjonowanie kobiet, ich pozycja społeczna, ich potrzeby, pragnienia i miejsca, jakie zajmowały w społeczeństwie, zmieniały się $z$ pokolenia na pokolenie. Podczas gdy jeszcze kilkadziesiąt lat temu podstawową rola kobiety była ta skoncentrowana na trosce o ognisko

W. Kymlicka, Współczesna filozofia polityczna, Kraków 1998, s. 265. 
domowe i potomstwo, to kobieta przełomu dwu ostatnich stuleci jest nie tylko matką i żona, lecz także kobietą aktywną zawodowo, która swój czas i siły dzieli między członków rodziny (męża, dzieci) oraz współpracowników w miejscu pracy.

Kobiety ostatnich lat XX i początku XXI w. różnią się znacznie od swoich rówieśniczek sprzed dwudziestu, trzydziestu, czterdziestu lat. Współczesne kobiety są otwarte na świat, nie boją się nowych wyzwań, przyjmuja nowe propozycje, są niezależne (choć w porównaniu do mężczyzn trudniej im zdobyć dobrze płatna pracę), twórcze, chętnie podnoszą swoje kwalifikacje, sprawniej niż ich poprzedniczki kontroluja swoje życie. W dzisiejszych czasach dla większej niż w latach poprzednich liczby kobiet praca zawodowa ma duże znaczenie i jest dziedzina, w której kobiety maja możliwość wykazać się szerokimi kwalifikacjami w niczym nieodbiegającymi od umiejętności mężczyzn.

Można zatem przyznać, że zmiany społeczne i gospodarcze zachodzące we współczesnym świecie, stwarzają warunki, które sprzyjaja zwiększeniu liczby kobiet na rynku pracy, współuczestniczeniu w procesie zarządzania, a także wzrostowi ich ambicji zawodowych.

Mimo że $z$ jednej strony kobiety stają się coraz bardziej aktywne w wielu obszarach życia społecznego, na rynku pracy czy w polityce, to jednak $z$ drugiej strony można wskazywać na wiele trudności i problemów zwiazanych $z$ ich pozycja i sytuacja. Biorac pod uwage np. sferę polityki czy biznesu, wyraźnie widać niedoreprezentowanie kobiet, szczególnie na najbardziej eksponowanych stanowiskach. Naturalne zatem wydaja się pytania o przyczyny takiej sytuacji. Rozważania w niniejszym tekście skoncentrowano na niezwykle - wydaje się - ważkich zagadnieniach zwiazanych $z$ problemami kobiet na rynku pracy. Celem jest zatem analiza wybranych uwarunkowań mających wpływ na udział kobiet na rynku pracy.

\section{Kobiety na rynku pracy - wybrane determinanty uczestnictwa}

Refleksje nad problematyką obecności kobiet na rynku pracy warto rozpoczać od wskazania czynników warunkujących ich 
obecność i partycypację. Zwrócić należy uwagę na kluczowe determinanty o charakterze kulturowym, społecznym czy gospodarczym danych społeczności, które to uwarunkowania maja istotny wpływ na sytuację i miejsce kobiet w życiu zawodowym.

W tym kontekście istotną wskazówką może być krótka analiza czynników utrudniajacych kobietom dostęp do rynku pracy ${ }^{2}$. Pierwsza kategoria barier warta wymienienia sa czynniki natury kulturowej. Praca zawodowa (szczególnie pełnienie kluczowych stanowisk w biznesie) rozumiana w sposób tradycyjny stanowi „sferę męską, obszar tradycyjnie przypisany mężczyznom, a w związu $z$ tym zdominowany przez mężczyzn, w którym nie ma tyle miejsca dla kobiet, co dla płci przeciwnej.

Dodatkowo za niezmiernie istotna przyczynę mniejszej obecności kobiet na rynku pracy uznać można przyjęty w danej kulturze proces socjalizacji, w trakcie którego dziewczęta i chłopcy przygotowywani sa do odgrywania odmiennych ról w społeczeństwie. Jest to zapewne wynik tradycyjnego definiowania roli obu płci. W konsekwencji takiego rozumienia przyjęto, że głównym zadaniem mężczyzn jest troska o bezpieczeństwo i zagwarantowanie odpowiednich warunków bytowych dla siebie i swojej rodziny. Kobiety natomiast mają do odegrania zupełnie inne role: ich głównym zadaniem ma być przede wszystkim podejmowanie aktywności w sferze prywatnej. W polskiej tradycji do najważniejszych zadań kobiet należało opiekowanie się ogniskiem domowym, wychowywanie dzieci czy wykonywanie prac porzadkowych w domu. $\mathrm{W}$ rezultacie - w powszechnym użyciu - pojawiło się swoiste określenie „Matka-Polka”. Należy również pamiętać, że proces socjalizacji przyczynia się do tego, że same społeczeństwa nie postrzegają kobiet jako tych, które moga i powinny sięgać po wysokie stanowiska w pracy zawodowej (ponieważ maja inne zadania w sferze prywatnej i nie będą w stanie pogodzić pełnienia obu funkcji), a same

2 Szerzej: M. Musiał-Karg, Kobiety $w$ organach władzy ustawodawczej oraz wykonawczej [w:] Kobiety we współczesnej Europie. Rola i miejsce kobiet na rynku pracy, $w$ polityce $i w$ społeczeństwie, red. M. Musiał-Karg, Torun 2009, s. 78-82. 
kobiety często nie dostrzegają swoich zalet, możliwości i predyspozycji do pełnienia takich ról ${ }^{3}$.

Niezwykle ważna przeszkodą w rozwoju ścieżki zawodowej kobiet są także funkcjonujące i często głęboko zakorzenione w społeczeństwach stereotypy społeczno-kulturowe. Wiąze się to $z$ występująca w wielu państwach idea patriarchatu, gdzie tradycyjny system wartości podkreśla naznaczony płcia podział ról, w którym nie ma przyzwolenia na zaangażowanie zawodowe kobiet lub też jest ono ograniczone do minimum ${ }^{4}$. Stereotypy na temat nieprzydatności kobiet do zajmowania wysokich stanowisk na rynku pracy występują w wielu krajach świata i sa podawane jako jeden $z$ argumentów usprawiedliwiających ich nieobecność bądź co najmniej wyraźne niedoreprezentowanie w sferze zawodowej. Dużą rolę $\mathrm{w}$ tym aspekcie odgrywaja media masowe, które w wielu przypadkach kreują taki właśnie stereotypowy wizerunek kobiety. W ich przekazach - szczególnie w spotach reklamowych - dostrzegalne sa przede wszystkim dwa podstawowe obrazy płci pięknej: „kobieta tradycyjna", której przypisuje się role matki, żony i pani domu gospodyni domowej, oraz „kobieta nowoczesna”, czyli taka, która jest przede wszystkim obiektem pożądania, specjalistką w dziedzinie kosmetyków lub środków czystości, profesjonalistką w tradycyjnie kobiecym zawodzie ${ }^{5}$. Można zatem potwierdzić, że media to niezwykle ważny czynnik opiniotwórczy, który poprzez tworzenie określonego portretu kobiet wpływa na postrzeganie ich oraz ich ról przez społeczeństwo.

W kontekście stereotypów (o których szerzej w dalszej części tekstu) warto zauważyć, iż w związku ze zmianami w postrzeganiu kobiet w przestrzeni publicznej i w społeczeństwie widoczny jest pewien powolny rozpad stereotypów związanych z płcia, czego do-

\footnotetext{
3 O. Barburska, Czynniki determinujace udział kobiet $w$ sprawowaniu władzy politycznej w krajach Europy Zachodniej, „Studia Europejskie” 2002, nr 2, s. 73.

4 Ibidem, s. 74.

5 J. Bator, Wizerunek kobiet $w$ reklamie telewizyjnej, Warszawa, sierpień 1998, s. 5.
} 
wodem jest np. coraz większa liczba kobiet zdobywających wyższe wykształcenie ${ }^{6}$.

Do wymienionych powyżej czynników kulturowych, które maja wpływ na postrzeganie kobiet w życiu zawodowym, zaliczyć też należy religię panująca w danym państwie. Według Olgi Barburskiej zwiększoną aktywność kobiet (w różnych obszarach życia społecznego, zawodowego czy politycznego) obserwuje się częściej w krajach protestanckich niż katolickich.

Przykładem ilustrującym tę prawidłowość może być Hiszpania, która jako państwo katolickie bardziej preferuje model kobiety-strażniczki ogniska domowego oraz protestanckie kraje skandynawskie, w których $z$ kolei idea aktywności zewnętrznej kobiet jest powszechnie akceptowana ${ }^{7}$.

Z kolei w państwach skandynawskich występuje kultura egalitarna, sprzyjająca szeroko rozumianemu równouprawnieniu kobiet i mężczyzn, w której zakorzeniona jest tradycja promująca ideę społecznej równości obu płci. Przekłada się to nie tylko na zwiększenie udziału kobiet na rynku pracy, ale także w przestrzeni politycznej, które sa wynikiem prowadzonych tam wielu działań skierowanych na zwiększenie udziału w życiu publicznym.

Bardzo ważnym - jak się wydaje - czynnikiem przekładającym się na obecność kobiet aktywnych zawodowo jest też zasięg działalności ruchów feministycznych - im więcej mówi się o feminizmie, im więcej jest miejsc, gdzie jest on rozpowszechniony, tym częściej mamy do czynienia $z$ większą liczbą kobiet obecnych na wysokich stanowiskach publicznych.

Uwarunkowania o charakterze socjoekonomicznym odgrywają również istotną rolę $\mathrm{w}$ postrzeganiu kobiet w obszarze zawodowym. Status społeczny i ekonomiczny kobiet w dużym stopniu wpływa na podejmowanie przez nie decyzji o aktywności zawodowej. Jako czynniki zaliczone do kategorii socjoekonomicznych wymienić można: dostęp do edukacji, ilość zasobów finansowych,

\footnotetext{
6 A. Marciniak, Niewidzialne bariery awansu kobiet - apokryf „szklanego sufitu”?, „Zeszyty Studiów Doktoranckich” 2004, z. 19, s. 5.

7 O. Barburska, op. cit., s. 74.
} 
dostęp do rynku pracy, bezrobocie, borykanie się z podwójnym obciążeniem pracą zawodową i domową. Prócz powyższych zwrócić należy też uwagę na ogólny poziom rozwoju gospodarczego kraju. Wysoki poziom tego wskaźnika przekłada się na większą emancypację kobiet m.in. poprzez wzrost poziomu urbanizacji czy wykształcenia, a przez to do większego zainteresowania kobiet pozadomową aktywnością, co z kolei przekłada się na większy udział kobiet na rynku pracy ${ }^{8}$.

\section{Utrudnienia w dostępie kobiet do rynku pracy}

Jak wspomniano powyżej, jedną $z$ przeszkód stojących na drodze rozwoju zawodowego kobiet sa stereotypy społeczno-kulturowe (koncentrujące się przede wszystkim na zagadnieniu nieprzydatności kobiet do zajmowania wysokich stanowisk), których funkcjonowaniem tłumaczy się często mały (w stosunku do mężczyzn) udział kobiet w sferze zawodowej.

Stereotypy zwiazane $z$ praca zawodowa kobiet maja zwykle charakter negatywny i przedstawiają zjawisko w sposób bardzo uproszczony. Jedna $z$ najbardziej popularnych badaczek problematyki zwiazanej ze stereotypami płci jest Eugenia Mandal - autorka licznych badań z zakresu psychologii ludzkiej płciowości: kobiecości i męskości, stereotypów płci, psychologii różnic płciowych. W swoim tekście pt. Seksizm a rynek pracy wymienia stereotypy najczęściej występujące $\mathrm{w}$ analizowanej dziedzinie. $Z$ racji ograniczonej objętości tekstu poniżej wyliczone zostana stereotypy (bez odniesienia do funkcjonujących realiów). Do najważniejszych stereotypów $\mathrm{Mandal}^{9}$ zalicza następujące:

- przekonanie, że kobiety nie musza podejmować pracy zawodowej, gdyż dysponują alternatywnym źródłem utrzymania (zarobki męża). Jeśli natomiast decyduja się już pracować, wcale nie musza zarabiać na poziomie podobnym do zarobków płci przeciwnej;

M. Musiał-Karg, op. cit., s. 80-81.

9 E. Mandal, Seksizm a rynek pracy, „Kobieta i Biznes” 1998, nr 3-4, s. 27 i n. 
- kobiety nie chca pracować zawodowo, nie maja ambicji robienia kariery zawodowej i rozwoju zawodowego;

- kobiety sa mniej rzetelnymi pracownikami i częściej sa nieobecne w pracy (m.in. ze względu na posiadanie potomstwa, którym częściej niż mężczyźni opiekuja się w przypadku choroby itp.);

- kobiety sa mniej zaangażowane w pracę zawodowa, sa do swojej pracy mniej przywiązane, dlatego też częściej podejmują decyzję o zmianie pracy;

- kobiety maja inne predyspozycje niż mężczyźni (sa np. mniej odporne na stres) i dlatego powinny wykonywać „kobiece" - lżejsze prace;

- kobiety nie potrafia być dobrymi kierownikami, przełożonymi, a mężczyźni nie chca pracować pod ich kierownictwem. Podłożem tego podejścia jest m.in. przekonanie o tym, że lepsze wzajemne zrozumienie występuje w relacji: „mężczyzna - podwładny i mężczyzna - przełożony” aniżeli w relacji „mężczyzna - podwładny i kobieta - przełożony";

- obecność kobiet w środowisku pracy zmniejsza koncentrację na pracy;

- kobiety odbieraja pracę mężczyznom;

- w rzeczywistości nie występuje zjawisko dyskryminacji zawodowej kobiet;

- kobiety maja mniejsze predyspozycje do pracy, bo nie sa głowami rodzin;

- kobiety lepiej znosza bezrobocie. Bezrobocie jest bardziej szkodliwe dla mężczyzn.

Jak wykazuja badania nad sytuacja kobiet na rynku pracy, wymienione powyżej stereotypy w większości przypadków nie maja nic wspólnego $z$ funkcjonujacca rzeczywistością ${ }^{10}$. Bez żadnych wątpliwości przyznać jednak należy, iż w sposób zdecydowany należy zapobiegać tworzeniu się takich mechanizmów, które będą utrwalały funkcjonowanie stereotypów we współczesnych społeczeństwach.

\footnotetext{
10 Szerzej na temat badań dot. stereotypów: I. Andruszkiewicz, Stereotypy pracy zawodowej kobiet $w$ Polsce i w UE [w:] Kobiety we współczesnej Europie..., s. 28-39.
} 


\section{Różnice w wynagrodzeniach}

Niezwykle ważnym problemem związanym $z$ obecnością kobiet na rynku pracy jest fakt, że zarabiają one mniej niż mężczyźni pracujący na tym samym bądź podobnym stanowisku (co też interpretowane jest jako przejaw nierówności). Według szacunków Eurostatu wśród państw członkowskich Unii Europejskiej można zaobserwować duże niejednorodności w tym obszarze.

Różnice płac sięgają od niecałych $10 \%$ w krajach takich jak Włochy, Malta, Polska, Słowenia, Rumunia, Portugalia i Belgia do ponad $20 \%$ w Słowacji, Holandii, Niemczech, Wielkiej Brytanii, Grecji oraz na Litwie i Cyprze. W przypadku Czech, Estonii i Austrii przekraczaja one $25 \%{ }^{11}$.

Różnic w poziomie zarobków obu płci nie należy traktować jako wskaźnika ogólnego stopnia równego traktowania kobiet i mężczyzn. Wynika to m.in. $z$ faktu, że wspomniany wskaźnik dotyczy wyłącznie osób pracujących zawodowo. Nierówności w wynagrodzeniu należy zatem rozpatrywać w kontekście innych wskaźników zwiąanych $z$ rynkiem pracy. Jak wskazano na stronach Komisji Europejskiej, różnica w poziomie wynagradzania kobiet i mężczyzn wiąże się $z$ różnymi wzorcami zatrudniania kobiet.

Tabela 1. Różnice w wynagrodzeniach kobiet i mężczyzn w państwach Unii Europejskiej (\%)

\begin{tabular}{|c|c|}
\hline Państwo & $\begin{array}{c}\text { Różnica w wy- } \\
\text { nagrodzeniach } \\
\text { kobiet i męż- } \\
\text { czyzn }\end{array}$ \\
\hline Belgia & 9,0 \\
\hline Bułgaria & 13,6 \\
\hline Czechy & 26,2 \\
\hline Dania & 17,1 \\
\hline
\end{tabular}

\begin{tabular}{|c|c|}
\hline Państwo & $\begin{array}{c}\text { Różnica w wy- } \\
\text { nagrodzeniach } \\
\text { kobiet i męż- } \\
\text { czyzn }\end{array}$ \\
\hline Luksemburg & 2,4 \\
\hline Węgry & 17,5 \\
\hline Malta & 9,2 \\
\hline Holandia & 19,6 \\
\hline
\end{tabular}

${ }_{11}$ Sytuacja $w$ UE. [online] [Dostęp: 12.09.2012]. Dostępny w World Wide Web: $<$ http://bit.ly/2zbUYe5>. 


\begin{tabular}{|c|c|}
\hline Niemcy & 23,2 \\
\hline Estonia & 30,3 \\
\hline Irlandia & 17,1 \\
\hline Grecja & 22,0 \\
\hline Hiszpania & 17,1 \\
\hline Francja & 19,2 \\
\hline Włochy & 4,9 \\
\hline Cypr & 21,6 \\
\hline Lotwa & 13,4 \\
\hline Litwa & 21,6 \\
\hline
\end{tabular}

\begin{tabular}{|c|c|}
\hline Austria & 25,5 \\
\hline Polska & 9,8 \\
\hline Portugalia & 9,2 \\
\hline Rumunia & 9,0 \\
\hline Słowenia & 8,5 \\
\hline Słowacja & 20,9 \\
\hline Finlandia & 20,0 \\
\hline Szwecja & 17,1 \\
\hline Wielka Brytania & 21,4 \\
\hline & \\
\hline
\end{tabular}

Źródło: Sytuacja w UE. [online] [Dostęp: 12.09.2012]. Dostępny $w$ World Wide Web: <http://bit.ly/2zbUYe5>.

W większości państw, w których odsetek kobiet pracujących zarobkowo jest niski (Malta, Włochy, Grecja, Polska), różnica jest niższa od średniej, co może wynikać $z$ niewielkiego udziału kobiet wśród pracowników niewykwalifikowanych. Wysoka wartość różnicy jest charakterystyczna dla rynków o dużym stopniu segregacji (np. Cypr, Estonia, Słowacja, Finlandia) lub dużym odsetku kobiet pracujących $\mathrm{w}$ niepełnym wymiarze godzin (np. Niemcy, Wielka Brytania, Holandia, Austria, Szwecja). Na wysokość różnicy maja również wpływ mechanizmy instytucjonalne i systemy ustalania płac ${ }^{12}$.

Przenosząc rozważania na grunt polski, zauważyć należy, że zgodnie $z$ wynikami Ogólnopolskiego Badania Wynagrodzeń w 2015 r. kobiety zarabiały przeciętnie 3400 PLN brutto miesięcznie, co stanowiło kwotę o 800 PLN mniejszą niż kwota wynagrodzenia mężczyzn. Panowie w tym czasie zarabiali 4200 PLN brutto ${ }^{13}$. Mediana wynagrodzeń kobiet stanowiła niespełna $81 \%$ wartości

\footnotetext{
12 Ibidem.

13 W 2015 r. w badaniu uczestniczyło 161224 osób (28,3\% więcej niż w 2014 r.). Ze względów metodologicznych w obliczeniach końcowych uwzględniliśmy dane 143010 respondentów. 63,3\% uczestników badania ma nie więcej niż 35 lat, 68\% mieszka w miastach powyżej 100 tys. mieszkańców, 69,2\% ma wykształcenie wyższe, 45,2\% pracuje w wielkich lub dużych przedsiębiorstwach, zaś $79,1 \%$ pracuje w firmach prywatnych.
} 
środkowej zarobków mężczyzn. Oznacza to, że luka płacowa (...) wyniosła $19 \%{ }^{14}$.

Dysproporcje w wynagrodzeniach kobiet i mężczyzn pojawiają się na wszystkich szczeblach zarządzania i nie są one zależne od stażu pracy. Największe różnice obserwowane sa na stanowiskach dyrektorskich. Zarobki kobiet odpowiadały $68 \%$ mediany wynagrodzeń mężczyzn na tych samych stanowiskach i $z$ tym samym stażem zawodowym. Nieco mniejsze dysproporcje odnotowano wśród pracowników szeregowych - tu zarobki pań stanowiły 92\% tego, co zarabiali mężczyźni. Jak wskazano w rezultatach badania realizowanego przez Sedlak \& Sedlak, występowanie różnic w pensjach było niezależne od wielkości przedsiębiorstw. Warto jednak odnotować, że wysokość wynagrodzenia w największym stopniu odnotowywana była w największych firmach. W przypadku wielkich przedsiębiorstw kobiety zarabiały przeciętnie 3833 PLN brutto, co stanowiło tylko $78 \%$ mediany wynagrodzeń mężczyzn ${ }^{15}$.

Uwzględniajacc kryterium pochodzenia kapitału formy, należy zauważyć, że zarówno w firmach polskich, jak i tych $z$ kapitałem zagranicznym występowały dysproporcje w poziomie zarobków kobiet i mężczyzn. W przedsiębiorstwach z przewaga polskiego kapitału kobiety zarabiały przeciętnie 3000 PLN brutto miesięcznie, co stanowiło niespełna $80 \%$ wartości środkowej pensji mężczyzn $\mathrm{w}$ polskich firmach. $Z$ kolei w organizacjach zagranicznych kobiety otrzymywały przeciętnie 4500 PLN, a ich koledzy 5500 PLN brutto miesięcznie ${ }^{16}$.

\footnotetext{
14 Ogólnopolskie Badanie Wynagrodzeń przeprowadzone przez Sedlak \& Sedlak w 2015 r., por. M. Hajec, Wynagrodzenia kobiet i mężczyzn w 2015 roku [w:] Wynagrodzenia.pl [online], [Dostęp: 07.07.2017]. Dostępny w World Wide Web: $<$ http://bit.ly/2zeEz8N>.

15 Ibidem.

16 Ibidem. Słusznie zauważono w badaniu, iż by poznać precyzyjne dane dot. badania różnic w zarobkach obu płci, należy wziąć pod uwage szereg cech, takich jak: wykształcenie, doświadczenie na rynku pracy czy rodzaj wykonywanej pracy.
} 
Wykres 1. Miesięczne wynagrodzenia całkowite kobiet i mężczyzn w firmach o różnym pochodzeniu kapitału (brutto w PLN)

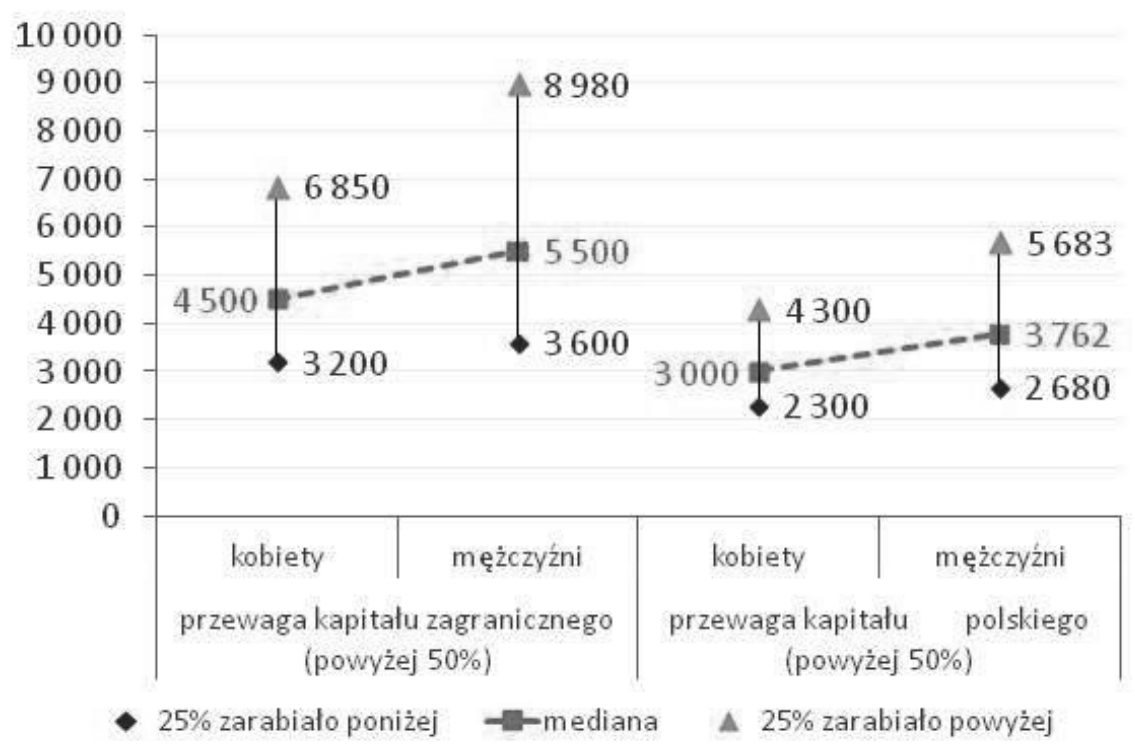

Źródło: Ogólnopolskie Badanie Wynagrodzeń przeprowadzone przez Sedlak \& Sedlak w 2015 r.

Segregacja zawodowa ze względu na płeć jest jedną $z$ przyczyn tego stanu rzeczy. O tym zjawisku mówi się, gdy - zwykle na podstawie stereotypowo przyjętego podziału na zajęcia „męskie” i „kobiece” - mężczyźni i kobiety skupieni sa w różnych zawodach i na odmiennych stanowiskach. Segregacja zawodowa ze względu na płeć to nierównomierna reprezentacja kobiet i mężczyzn w poszczególnych dziedzinach aktywności zawodowej. Ma dwa wymiary: poziomy i pionowy. Segregacja pozioma/horyzontalna (ang. horizontal segregation) to tendencja, żeby kobiety i mężczyźni wykonywali odmienne zawody. Polega na skoncentrowaniu aktywności zawodowej kobiet i mężczyzn w określonych sektorach zatrudnienia i w określonych zawodach. Zjawisko segregacji poziomej prowadzi do dyskryminacji kobiet poprzez dyskryminację sfeminizowanych zawodów, które uważane sa za mniej ważne i prestiżowe, a co za tym idzie - sa znacznie gorzej opłacane. Segregacja pionowa/hierarchiczna (ang. vertical segregation) polega natomiast na skon- 
centrowaniu kobiet i mężczyzn na określonych szczeblach służbowych i stanowiskach w strukturze zatrudnienia. W tej sytuacji - w przeciwieństwie do mężczyzn - kobiety zajmuja zwykle niskie stanowiska w hierarchii zawodowej. Jak zaznacza Joanna Tomaszewska, w wielu obszarach aktywności zawodowej zaobserwować można swoista piramidę, u podstawy której (czyli na niskich stanowiskach) jest bardzo dużo kobiet, na szczycie hierarchii zaś (czyli na stanowiskach decyzyjnych) występuje widoczna przewaga mężczyzn. Obserwuje się to zarówno w strukturze poszczególnych instytucji czy organizacji, jak i np. w grupach zawodowych.

Tam, gdzie mamy do czynienia z mniej dochodowymi, mniej liczacymi się sposobami wykonywania danego zawodu, będzie więcej kobiet. Stanowiska bardziej prestiżowe, łączące się $z$ większymi zarobkami i większą władza, przeważnie obejmują mężczyźni. Dzieje się tak w polityce (np. w partiach politycznych), w sądownictwie, na wyższych uczelniach, w związkach zawodowych, w mediach, we wszystkich obszarach aktywności publicznej, a nawet w tak sfeminizowanych zawodach, jak szkolnictwo, gdzie ok. $80 \%$ zatrudnionych to kobiety ${ }^{17}$.

Do zawodów sfeminizowanych należą następujące branże gospodarki narodowej: edukacja, ochrona zdrowia i pomoc społeczna, pośrednictwo finansowe, hotele i restauracje. Równowaga płci w dziedzinie zatrudnienia występuje w administracji publicznej. $Z$ niewielka przewaga zatrudnionych kobiet mamy do czynienia w sekcji handel i naprawy oraz w działalności usługowej o charakterze komunalnym, społecznym i indywidualnym. Niewielka przewaga mężczyzn występuje zaś w rolnictwie, łowiectwie i leśnictwie. Zmaskulinizowanymi dziedzinami są: budownictwo, górnictwo, transport, gospodarka magazynowa i łączność, wytwarzanie i zaopatrywanie $\mathrm{w}$ energię elektryczna, gaz i wodę, przetwórstwo przemysłowe, obsługa nieruchomości i firm. Jeśli chodzi o grupy zawodowe, to najwięcej zatrudnionych kobiet jest wśród pracow-

17 J. Tomaszewska, Dyskryminacja ze względu na płeć [w:] Dyskryminacja ze względu na płeć i jej przeciwdziałanie, Warszawa 204, s. 9-10. 
ników biurowych, pracowników usług osobistych i sprzedawców oraz wśród specjalistów ${ }^{18}$.

Należy w tym miejscu zaznaczyć, że segregacja ma niewątpliwie charakter dyskryminujący, ponieważ ogranicza jednostkom prawo wyboru. Ponadto dyskryminuje kobiety, gdyż to im przypadają w udziale zajęcia źle opłacane, rutynowe, niedające możliwości rozwoju, awansu i satysfakcji.

Oprócz stereotypów płciowych, niższych wynagrodzeń kobiet czy segregacji zawodowej, warto wspomnieć o terminach, które utarły się $\mathrm{w}$ dyskusji na temat roli i miejsca kobiet na rynku pracy. Pierwszym $z$ nich jest określenie „szklany sufit”. „Szklany sufit" w dostępie kobiet do stanowisk kierowniczych to niewidzialna bariera, która stoi na kolejnych szczeblach kariery i uniemożliwia awans na najwyższe stanowiska. To niewidoczne, formalnie nieistniejące przeszkody, to symbol pseudomożliwego awansu przy jego niedostępności ${ }^{19}$. Jak pokazuja wyniki badań prowadzonych w USA, większość kobiet (52\%) zatrudnionych na stanowiskach kierowniczych potwierdza istnienie „szklanego sufitu”, podczas gdy mężczyźni (82\%) temu zaprzeczają, twierdząc, że kobiety nie maja odpowiedniego doświadczenia/kwalifikacji. Zjawisko to jest wzmacniane przez homogeniczność kadry menedżerskiej, szczególnie najwyższych szczebli ${ }^{20}$. Kolejnym terminem wartym wspomnienia i pokrewnym do "szklanego sufitu” sa "szklane ściany”. Wiąże się to $z$ utrudnieniem $w$ awansie ze stanowiska pomocniczego na kierownicze. Zjawisko dotyczy przede wszystkim kobiet zatrudnionych $\mathrm{w}$ biurach, w sekretariatach. Mimo posiadanych kwalifikacji nie moga awansować np. z powodu braku doświadczenia na stanowiskach kierowniczych. „Lepka podłoga” to $z$ kolei określenie powiązane ze „szklanymi ścianami”, dotyczące posad, $z$ których trudno awansować. Sa to przeważnie stanowiska pomoc-

\footnotetext{
18 Za: E. Lisowska, Kobiety na rynku pracy: dyskryminacja czy równość? [w:] Kobiety we współczesnej Europie..., s. 14-15.

19 Szklany sufit. Bariery $i$ ograniczenia karier kobiet, red. A. Titkow, Warszawa 2003, s. 8-9.

20 Badania amerykańskie za: L. Brannon, Psychologia rodzaju. Kobiety i mężczyźni: podobni czy różni, Gdańsk 2002.
} 
nicze: asystentki, sekretarki, tłumaczki. „Szklane ruchome schody" natomiast to termin odnoszacy się do sytuacji uprzywilejowania mężczyzn w zawodach tradycyjnie uprawianych przez kobiety. To zjawisko wznoszące mężczyzn na wyższe szczeble kariery zawodowej - jest ono przeciwieństwem „szklanego sufitu” i przejawia się m.in. w przekonaniu, że mężczyznom nie przystoi pracować w zawodach kojarzonych $z$ kobietami. Panowie wykonujacy „kobiece zawody" sa awansowani na stanowiska zarządców czy nadzorców. Ponadto zauważalny jest fakt, iż w tak sfeminizowanych zawodach jak nauczyciel czy urzędnik o wiele częściej dyrektorami szkół są mężczyźni, a kierownicze funkcje w administracji również piastowane są częściej przez panów.

\section{Podsumowanie}

Zagadnienie nierównych szans płci na rynku pracy jest bardzo dotkliwe dla kobiet i stanowi palący problem społeczny. Dzisiejsza kobieta ma wcią̇̇ mniejsze w porównaniu $z$ mężczyzną szanse nie tylko na znalezienie odpowiadającej jej pracy, ale także na dobre wynagrodzenie czy wysokie stanowisko. Bezrobocie wśród kobiet może mieć poważne społeczne konsekwencje, ponieważ jest to czynnik zagrażajaccy statusowi i stabilności ekonomicznej rodziny bezrobotnej, którego rezultatem może być poczucie społecznego wykluczenia. W większości przypadków brak pracy nie jest świadomym wyborem kobiet, a skutkiem warunków panujacych na rynku pracy, ograniczających szanse na zatrudnienie kobiet. Warto w tym kontekście wspomnieć, że uwarunkowań sytuacji kobiet na rynku pracy należy szukać również (oprócz czynników wspomnianych powyżej) w czynnikach odnoszących się do samych kobiet, które czasami same się dyskryminuja, nie wierzac w swoje siły i nie podejmujacc odważnie wyzwań zawodowych. Samodyskryminacja jest czynnikiem pogłębiającym nierówności płciowe na rynku pracy.

Podsumowując rozważania na temat sytuacji kobiet na rynku pracy, można stwierdzić, iż kobiety należą do grupy osób, którym trudniej jest się odnaleźć na rynku pracy. Stąd też przed poszczególnymi rządami, władzami samorządowymi, organizacja- 
mi i instytucjami działającymi w obszarze rynku pracy stoja nowe wyzwania, których celem winno być niwelowanie niekorzystnej dla kobiet sytuacji. Niezaprzeczalny jest również fakt, że podobne wyzwania stoja przed samymi kobietami.

Podsumowując niniejsze rozważania, należy przypomnieć, że równość kobiet i mężczyzn jest jedna $z$ fundamentalnych wartości Unii Europejskiej. Instytucje unijne uwzględniaja tę zasadę w swojej działalności, czego dowodem jest choćby fakt, iż już postanowienia traktatów rzymskich odnosiły się do zapewnienia równego wynagrodzenia ${ }^{21}$. Stosowanie zasady równości wynagrodzeń dla pracowników obu płci za taką sama pracę lub pracę takiej samej wartości gwarantuje art. 157 Traktatu o Funkcjonowaniu Unii Europejskiej $^{22}$. Ponadto odnosi się do tego dyrektywa 2006/54/WE Parlamentu Europejskiego i Rady z dnia 5 lipca 2006 r. $w$ sprawie wprowadzenia $w$ życie zasady równości szans oraz równego traktowania kobiet $i$ mężczyzn $w$ dziedzinie zatrudnienia $i$ pracy ${ }^{23}$, która uchyliła wcześniejsze dyrektywy obowiazujace w tym zakre$\mathrm{sie}^{24}$. W grudniu 2015 r. na forum UE nasilono działania mające wprowadzać równość płci, czego wyrazem było przyjęcie dokumentu „Strategiczne zaangażowanie na rzecz równości płci” na lata 2016-201925.

W marcu 2017 r. opublikowano raport 2017 report on equality between women and men in the European Union ${ }^{26} \mathrm{z}$ przeglądu głównych unijnych działań z 2016 r. w dziedzinie równości płci. W dokumencie stwierdzono, że w wielu obszarach swojej działalności kobiety nadal napotykaja szereg barier utrudniających ich

\footnotetext{
21 Międzynarodowy Dzień Kobiet 2017: Nowe sprawozdanie UE nt. równości kobiet $i$ mężczyzn [w:] NGO.pl [online] 9.03.2017, [Dostęp: 20.07.2017]. Dostępny w World Wide Web: <http://bit.ly/2AQcvF2>.

22 Traktat o Funkcjonowaniu Unii Europejskiej z dnia 30 kwietnia 2004 r., Dz.U. Nr 90, poz. $864 / 2$, z późn. zm.

${ }^{23}$ Dz.Urz. UE L 204 z 26 lipca 2006 r.

24 J. Tracz-Dral, Dyskryminacja w zatrudnieniu ze względu na płeć, OT-618 Biuro Analiz i Dokumentacji, Zespół Informacji i Statystyk, Kancelaria Senatu, Luty 2013, s. 15.

25 Międzynarodowy Dzień Kobiet 2017..., <http:/ / bit.ly/2AQcvF2>.

${ }_{26} 2017$ report on equality between women and men in the European Union, European Union 2017.
} 
zaangażowanie. Do najważniejszych wniosków ukazujących sytuację kobiet wpisano:

- stopa bezrobocia wśród kobiet pozostaje na bardzo wysokim poziomie $\mathrm{w}$ porównaniu $\mathrm{z}$ bezrobociem wśród mężczyzn, zwłaszcza w krajach południa Europy;

- we wszystkich państwach UE kobiety nadal zarabiaja średnio o 40 proc. mniej niż mężczyźni, a różnica w emeryturach kobiet i mężczyzn utrzymuje się na poziomie 38 proc. (...);

- szklany sufit nadal istnieje: tylko w czterech krajach (Francja, Włochy, Finlandia i Szwecja) w zarządach dużych spółek jest co najmniej 30 proc. kobiet ${ }^{27}$.

Niniejszy tekst nie stanowi całościowej analizy problemu i pomyślany został jako przyczynek do dalszej dyskusji nad sytuacja kobiet na rynku pracy oraz czynnikami wpływajacymi na ich obecność w tej przestrzeni.

\section{Bibliografia}

\section{Źródła}

Traktat o Funkcjonowaniu Unii Europejskiej z dnia 30 kwietnia 2004 r., Dz.U. Nr 90, poz. 864/2, z późn. zm.

Dz.Urz. UE L 204 z 26 lipca 2006 r.

2017 report on equality between women and men in the European Union, European Union, 2017, ISSN 2443-5228.

\section{Opracowania}

Andruszkiewicz Iwetta, Stereotypy pracy zawodowej kobiet $w$ Polsce i w UE [w:] Kobiety we współczesnej Europie. Rola i miejsce kobiet na rynku pracy, $w$ polityce $i w$ spoleczeństwie, red. Magdalena Musiał-Karg, Toruń : Wydawnictwo Adam Marszałek, 2009, s. 28-39, ISBN 978-83-7611-502-3.

Bator Joanna, Wizerunek kobiet $w$ reklamie telewizyjnej, Warszawa : Instytut Spraw Publicznych, sierpień 1998.

${ }_{27}$ Międzynarodowy Dzień Kobiet 2017..., <http://bit.ly/2AQcvF2>. 
Brannon Linda, Psychologia rodzaju. Kobiety i mężczyźni: podobni czy różni, Gdańsk : Gdańskie Wydawnictwo Psychologiczne, 2002, ISBN 8387957-63-1.

Kymlicka Will, Współczesna filozofia polityczna, Kraków : Znak, 1998, ISBN 83-7006-725-5.

Musiał-Karg Magdalena, Kobiety w organach władzy ustawodawczej oraz wykonawczej [w:] Kobiety we wspótczesnej Europie. Rola i miejsce kobiet na rynku pracy, $w$ polityce $i w$ spoleczeństwie, red. Magdalena Musiał-Karg, Toruń : Wydawnictwo Adam Marszałek, 2009, s. 78-82, ISBN : 978-83-7611-502-3.

Szklany sufit. Bariery i ograniczenia karier kobiet, red. Anna Titkow, Warszawa ISP, 2003.

Tracz-Dral Jagoda, Dyskryminacja w zatrudnieniu ze względu na pleć, OT618 Biuro Analiz i Dokumentacji, Zespół Informacji i Statystyk, Kancelaria Senatu, Luty 2013, s. 15.

\section{Artykuły naukowe}

Barburska Olga, Czynniki determinujace udział kobiet $w$ sprawowaniu władzy politycznej $w$ krajach Europy Zachodniej, „Studia Europejskie” 2002, nr 2, s. 69-93, ISSN 1428-149X.

Lisowska Ewa, Kobiety na rynku pracy: dyskryminacja czy równość? [w:] Kobiety we wspólczesnej Europie. Rola i miejsce kobiet na rynku pracy, $w$ polityce i $w$ społeczeństwie, red. Magdalena Musiał-Karg, Toruń Wydawnictwo Adam Marszałek, 2009, ISBN 978-83-7611-502-3.

Mandal Eugenia, Seksizm a rynek pracy, „Kobieta i Biznes” 1998, nr 3-4, s. 27-30, 68-71, ISSN 1230-94-27.

Marciniak Anna, Niewidzialne bariery awansu kobiet - apokryf „szklanego sufitu”?, „Zeszyty Studiów Doktoranckich” 2004, z. 19, s. 5-19, ISSN 1642-2600.

Tomaszewska Joanna, Dyskryminacja ze względu na płeć [w:] Dyskryminacja ze względu na płeć i jej przeciwdziałanie, Warszawa : Sekretariat Pełnomocnika Rządu do Spraw Równego Statusu Kobiet i Mężczyzn, 2004. 


\section{Zasoby internetowe}

Międzynarodowy Dzień Kobiet 2017: Nowe sprawozdanie UE nt. równości kobiet $i$ mężczyzn. [w:] NGO.pl [online]. 9.03.2017 [Dostęp: 20.07.2017]. Dostępny w World Wide Web: <http://bit.ly/2AQcvF2>. Sytuacja $w$ UE. [online]. [Dostęp: 12.09.2012]. Dostępny w World Wide Web: <http://bit.ly/2zbUYe5>.

Hajec Maria, Wynagrodzenia kobiet i mężczyzn w 2015 roku. [w:] Wynagrodzenia.pl [online]. [Dostęp: 07.07.2017]. Dostępny w World Wide Web: <http:// bit.ly/2zeEz8N>. 